\title{
THE ROLE OF ADVANCED WASTE-TO-ENERGY TECHNOLOGIES IN LANDFILL MINING
}

\author{
CRISTINA ARACIL, PEDRO HARO \& ALBERTO GÓMEZ-BAREA \\ Bioenergy Group, Chemical and Environmental Engineering Department. \\ Escuela Técnica Superior de Ingeniería, \\ Universidad de Sevilla, Spain
}

\begin{abstract}
Recently, the European Parliament has decided to include a specific reference to "Enhanced Landfill Mining" (ELFM) in the Landfill Directive proposing a regulatory framework for ELFM so as to permit the retrieval of secondary raw materials that are present in existing landfill sites. Recent studies are supporting ELFM since they consider that landfill mining would be economically feasible only if combined with energy recovery (i.e., waste-to-energy, WtE) and if a wide range of materials are recovered (i.e., waste-to-materials, WtM). In this study, a combined material (landfill mining) and energy (advanced WtE) recovery is proposed where the excavated waste (MSW refuse) can be directly recycled or pretreated and used in the production of refuse-derived fuel (RDF) for an advanced (gasification-based) WtE plant producing power and heat. Both material and energy recovery are challenging in the circular economy since contributes to a loop-closing objective in human activities. An exhaustive assessment of each particular landfill site must be carried out in order to determine the profitability of the ELFM.
\end{abstract}

Keywords: MSW refuse, landfill mining, waste gasification, waste-to-materials, LCA.

\section{INTRODUCTION}

\subsection{Perspectives on landfill mining in Europe}

In the last decades, regulation efforts aiming at the reduction of landfill disposal have been put forward by the European Union. Both recycling and energy recovery from municipal solid waste (MSW) have been promoted as a sustainable alternative to landfill disposal. Recently, the European Parliament has decided to include a specific reference to "Enhanced Landfill Mining" (ELFM) in Landfill Directive [1], proposing a regulatory framework for ELFM so as to permit the retrieval of secondary raw materials that are present in existing landfills.

Landfill mining (LFM) represents a new concept of mining where solid wastes that have previously been landfilled are excavated and processed for the recovery of high-value low-volume materials. ELFM represents the state of the art of LFM, an improved practice of landfill mining. From this point of view, ELFM aims to integrate landfilling in a sustainable context where landfill sites are considered as temporary storage places awaiting further treatment or as future mines for feedstock (secondary sources) [2]. According to the state of the technology and the type and form of the wastes, recovery can be more focused on materials (Waste-to-Materials, WtM) or energy (Waste-to-Energy, WtE). Both WtM and WtE play an important role in a loop-closing concept, therefore, it is important to ensure that the composition and characteristics of the landfilled waste fulfil the requirements of a $\mathrm{WtE}$ plant input. In the case of WtM, ELFM allows recovering rare earth elements, i.e. La, Ce, Pr, $\mathrm{Nd}$ and $\mathrm{Sm}$; platinum group metals, critical metals, i.e. $\mathrm{Li}, \mathrm{In}, \mathrm{Co}$, and $\mathrm{Sb}$, highly valuable metals, i.e. $\mathrm{Al}$ and $\mathrm{Cu}$; and additional materials (plastics, paper, glass, ferrous metals and other). Rare earth elements are currently much demanded since they are present in electric 
and electronic items like mobile phones or computers. However, there is no production capacity for these elements in Europe; it is hence interesting to recover them from landfill sites [3].

According to the waste hierarchy [4], recycling (in this case on the form of WtM) should be prioritized versus energy recovery (WtE) and the latter versus landfill disposal in order to protect the environment. In fact, landfilling is usually considered to produce higher emissions than energy recovery [5]-[7]. Finally, the non-recoverable materials can be landfilled again in order to be excavated and processed (recycled) in the future. In any cases, the landfill volume and pollution associated to it are considerably reduced. Bottom ash from energy recovery in ELFM contains sand, stones, ashes from burnt materials and metals. Table 1 shows the recovery potential of metals from bottom ash according to [8]. The presence of huge amount of low-value high-volume materials like aluminium, calcium or silicon could compensate the economic impact in the recovery of more valuable but low-volume metals like cobalt or antimony since the metals are dispersed and their chemical form (oxides) makes a profitable extraction difficult.

Hence, ELFM enables the recovery of valuable materials which can be brought back into the cycle and also allows for recovering land area. However, the uncertainties associated to LFM require an exhaustive assessment about the type and age of the landfill site, its location (country or region) and available technologies to manage the wastes. Therefore, a techno-economic and GHG emission assessment of ELFM must be carried out.

From the economic point of view, recent studies on LFM consider this would be economically feasible only if combined with energy recovery (WtE) and additional materials (plastics, paper, glass, ferrous metals and other) were recovered at the site [9], i.e., ELFM. Zhou et al., 2015 [10], summarizes the top three costs and benefits of combined WtM and

Table 1: Recovery potential of ELFM according to [8], in terms of mg per kg of produced bottom ash.

\begin{tabular}{|c|c|c|c|}
\hline $\begin{array}{c}\text { Trace } \\
\text { metals }\end{array}$ & $\begin{array}{c}\text { Bottom ash } \\
(\mathrm{mg} / \mathrm{kg})\end{array}$ & $\begin{array}{c}\text { Trace } \\
\text { metals }\end{array}$ & $\begin{array}{c}\text { Bottom ash } \\
(\mathrm{mg} / \mathrm{kg})\end{array}$ \\
\hline $\mathrm{Al}$ & 218,438 & $\mathrm{Cr}$ & 124.7 \\
\hline $\mathrm{Ca}$ & 122,073 & $\mathrm{Cu}$ & 62.2 \\
\hline $\mathrm{Fe}$ & 49,357 & $\mathrm{Ni}$ & 15.2 \\
\hline $\mathrm{Mg}$ & 14,165 & $\mathrm{~V}$ & 48.2 \\
\hline $\mathrm{P}$ & 446.6 & $\mathrm{Zn}$ & 46.4 \\
\hline $\mathrm{Si}$ & 141,825 & $\mathrm{Co}$ & 3.3 \\
\hline $\mathrm{K}$ & 2,593 & $\mathrm{Mn}$ & 12,754 \\
\hline $\mathrm{Na}$ & 5,291 & $\mathrm{~Pb}$ & 10.0 \\
\hline $\mathrm{Ti}$ & 12,385 & $\mathrm{Sb}$ & 4.1 \\
\hline $\mathrm{Tl}$ & 0.1 & $\mathrm{As}$ & 1.7 \\
\hline
\end{tabular}


WtE. On the one hand, rental of excavation and hauling equipment, waste processing and material transportation are considered the top three costs of ELFM, however, the use of the equipment and infrastructure already available in current mechanical biological treatment (MBT) plants would allow reducing these costs. On the other hand, the top three benefits of ELFM are electricity generation by incineration, land reclamation and recycling soil-like materials. Therefore, more energy recovery alternatives must be assessed in order to increase the benefits. Moreover, avoided costs from landfilling should be added since the timing of storage is shortened and costs about maintenance and degasification are reduced.

\subsection{The role of MSW refuse in bioenergy}

The urgent need of reducing GHG emissions in order to limit global warming makes the search of alternatives to the use of fossil fuels essential [11]. Moreover, waste disposal in some European countries (landfilling or incineration without energy recovery) should be replaced by waste-valorization alternatives in order to fulfil the objectives of the circular economy [12]. MSW refuse is the unsorted stream of MSW going to landfill disposal or incineration. This stream has two possible origins depending of the waste collection method. The first one is the fraction not separated at source and collected in a communal bin. The second one, it is the refuse of MBT plants fed by a mix of wastes and where the compostable and recyclable fraction has been previously separated (Fig. 1). This fraction is partially biodegradable, so it is not considered as pure biomass. However, MSW refuse usually contains a biodegradable fraction over 50\% [13] and therefore, it could be interesting use it as feedstock for bioenergy production [14]-[16].

The studied concept of advanced WtE plant is a facility producing products and/or services from MSW refuse e.g. by means of gasification (partial combustion) to produce a syngas, where the latter is further used for the production of power and/or heat. Different technologies can be used in an advanced WtE plant. In a previous work, the authors presented the most common technologies that were economically and GHG emission-assessed. Moving grate and fluidized bed reactors for the production of the syngas and steam Rankine cycle (SRC), organic Rankine cycle (ORC) and internal combustion engine (ICE) for the production of electricity are all examples of processes that could be used [17].

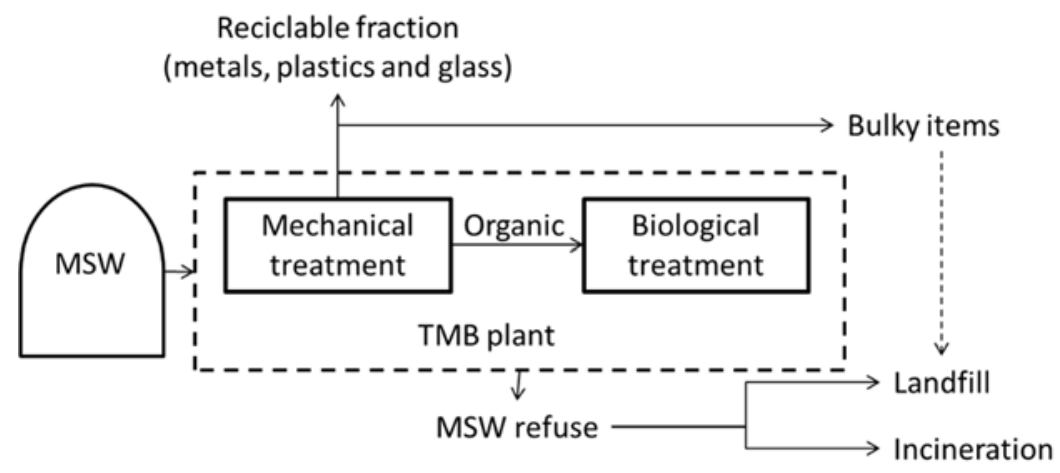

Figure 1: Diagram about how the MBT plants operate and the fractions generated. MSW refuse usually goes to landfill disposal or incineration. 
Fluidized bed gasification (FBG) technologies require a homogeneous fuel, so that the MSW refuse has to be pretreated and converted into refuse-derived fuel (RDF). Moving-grate gasifiers can generally be operated with direct MSW refuse but the lower technical development of gasification compared to incineration suggests to pretreat the refuse in order to improve the availability of the gasification process and to increase the heating value of the feedstock. Moreover, RDF production can reduce the presence of elements such as chlorine, sulphur and heavy metals in MSW refuse that affect the quality of final products and coproducts (syngas, fly and bottom ashes).

\subsection{Current situation of landfilling in Europe}

In Europe, MSW management is based on recycling, incineration (with and without energy recovery) and landfilling [18]. Fig. 2 shows the European average of each treatment highlighting the differences between Northern and Southern European countries. In fact, landfilling is dominant in the Southern and Eastern European countries, e.g. in Spain 55\% of the MSW generated is landfilled every year whereas in the Northern Europe, landfilling ratio is below incineration and recycling ratios, even negligible in some countries (zero landfilling is declared in Germany).

Landfilling being a common practice before 2000, numerous closed landfills can be found widespread all over Europe. For a long time, landfilling was a non-selective disposal way in which a heterogeneous mix of wastes was buried. A lot of these landfills sites were closed even before the promotion of recycling, so they contain many recyclable materials as well as solid fuels and construction materials (agglomerates, metals, etc.). In Southern and Eastern Europe, the current high landfilling and low recycling and incineration ratios cause that valuable materials, (such as valuable metals), are still being landfilled. Therefore, there are more and more accumulation of landfilled materials whereas raw materials availability is getting scarce. In Spain, it is estimated that there is 275 million of landfilled waste in which $20-30 \%$ are fuels and $2-5 \%$ are metals [3].

Landfill disposal requires the use of land that is not always available and is associated with several environmental impacts over land, atmosphere, hydrosphere and biosphere. Recent studies show that methane concentration in the atmosphere dramatically rose in the last decades. This methane is released from different sources but two thirds of the emissions are related to anthropogenic activities linked to agriculture and waste management. In the waste sector, landfilling represents an important source of methane emissions. Mitigation strategies (covering and degasifying landfills) are determinant to reduce $\mathrm{CH}_{4}$ emissions [19], [20]. However, landfill-dominant European countries should also encourage wastevalorization initiatives in order to minimize GHG emissions and approach EU legislation [21].

From an environmental point of view, emissions from landfilling are higher than those from the advanced WtE plant [22]-[25].

\section{GOAL AND SCOPE}

In this study, a combined material (LFM) and energy (advanced WtE) recovery is proposed where the excavated waste (MSW refuse) could be directly recycled or pre-treated and used in the production of RDF for an advanced $\mathrm{WtE}$ plant. This is part of a greater objective that is the loop-closing. Fig. 3 shows the scope of this study where MSW refuse from landfill site feeds an advanced WtE plant based on gasification while the materials are recovered in the MBT plant and from bottom and fly ashes. 


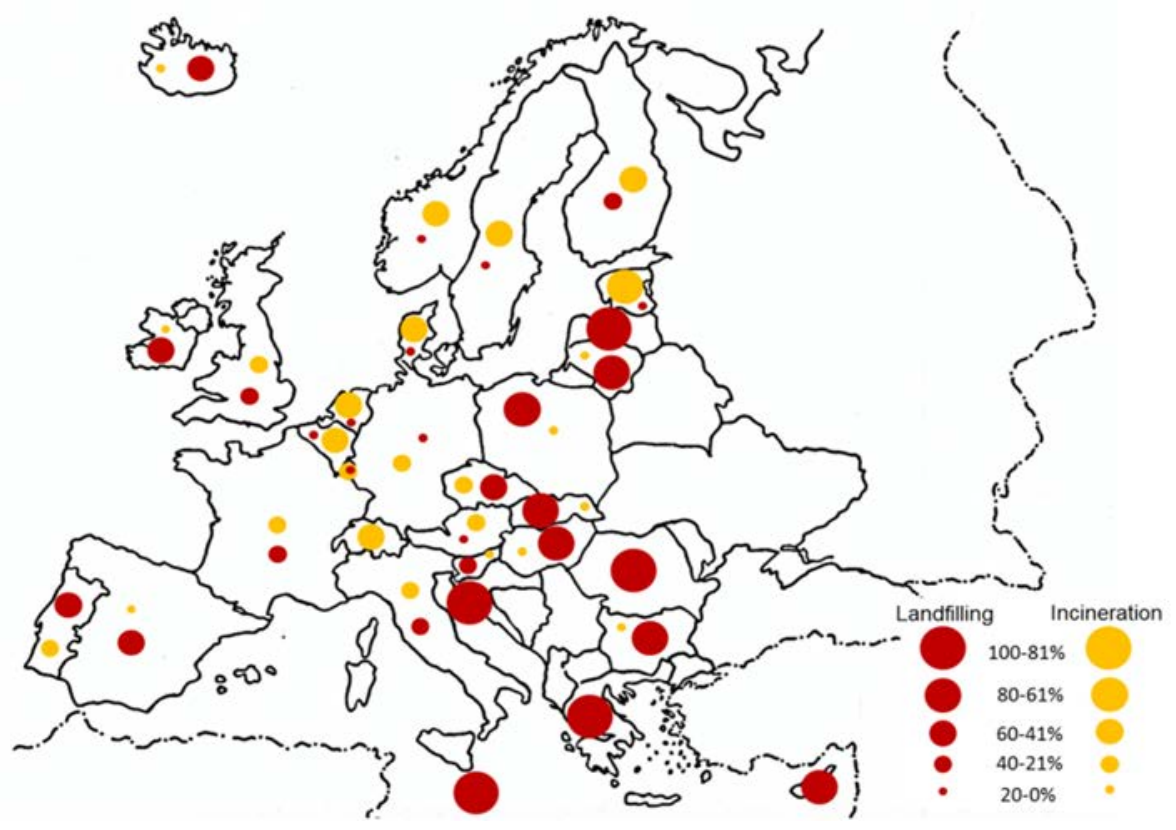

Figure 2: Landfilling and incineration ratios of MSW refuse in Europe [22].

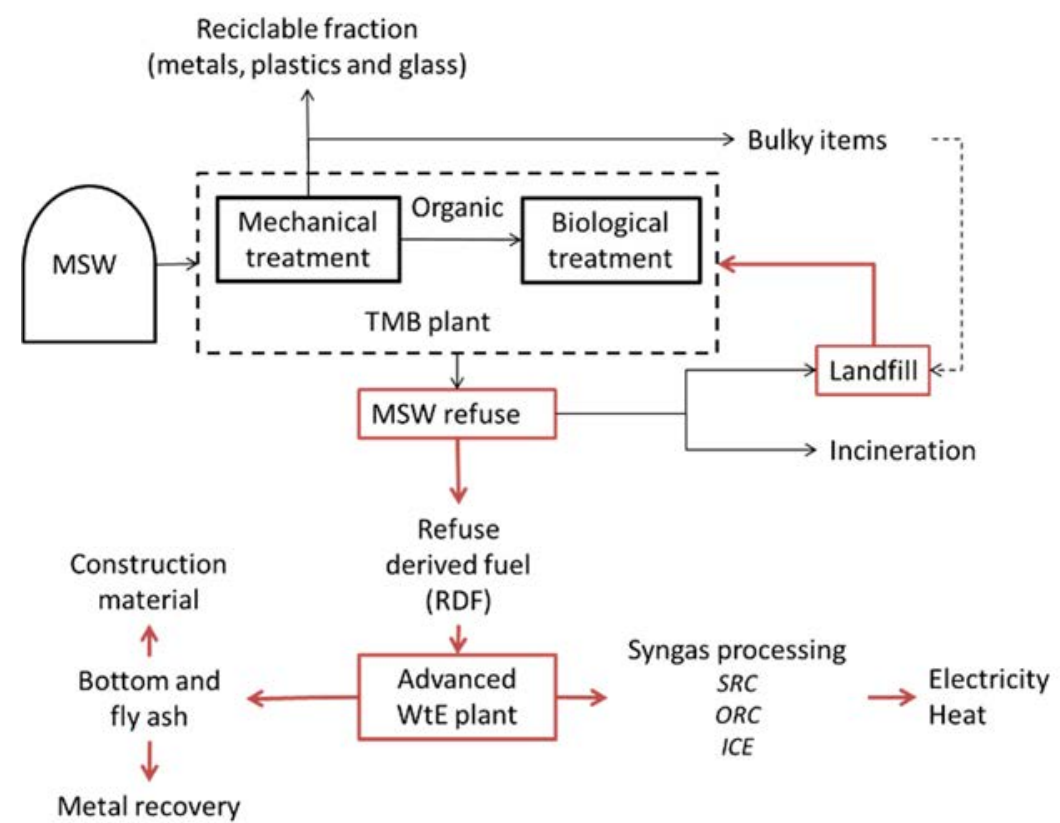

Figure 3: Proposal of combining material and energy recovery on landfill mining in this study. 


\section{DISCUSSION AND CONCLUSIONS}

A combined material (LFM) and energy recovery (advanced WtE plant) from a historical landfill (i.e., ELFM) involves a challenge within a circular economy concept. Metals can be recovered from MSW refuse recycling or pre-treatment or from bottom and fly ashes. Costs can be reduced using the available equipment of existing MBT plants. However, an exhaustive assessment of each particular landfill site must be carried out in order to determine the profitability of the process.

\section{ACKNOWLEDGEMENTS}

This work has been supported by the Spanish Ministry of Economy and Competitiveness and carried out in the framework of the BIOTER project (Proyecto de Investigación Fundamental No-Orientada; grant number ENE2012-31598) and NETuWAS (Proyecto I+D - Retos; grant number CTM2016-78089-R). Pedro Haro thanks the Universidad de Sevilla for the postdoctoral Grant Contrato de Acceso al Sistema Español de Ciencia, Tecnología e Innovación (VPPI-US).

\section{REFERENCES}

[1] EURELCO Newsletter 13. European Parliament votes YES to include Enhanced Landfill Mining in the EU Landfill Directive. March 2017 http://us7.campaignarchive1.com/?u=4480d0d957f687434609fbc25\&id=4c8067c0ef\&e=786a8baaf6.

[2] Bosmans, A., Vanderreydt, I., Geysen, D. \& Helsen, L., The crucial role of Waste-toEnergy technologies in enhanced landfill mining: A technology review, Journal of Cleaner Production, 55, pp. 10-23, 2013.

[3] Professional residues (Residuos profesional) https://issuu.com/residuospro/docs/ mineria_vertederos $/ 2$ ?ff $=$ true $\& \mathrm{e}=10860877 / 13271585 \mathrm{https}: /$ Accessed on: 10 May 2017.

[4] Directive 2008/98/EC of the European Parliament and of the Council of 19 November 2008 on waste and repealing certain Directives. http://eur-lex.europa.eu/legalcontent/EN/TXT/PDF/?uri=CELEX:32008L0098\&from=EN

[5] Clausen, A. \& Pretz, T., The Relevance of Framework Conditions for Modelling GHG Emissions from rMSW Treatment Systems in EU. Waste and Biomass Valorisation; 7(1), pp.175-191, 2016.

[6] Fiorentino, G., Ripa, M., Protano, G. \& Hornsby, C. \& Ulgiati S., Life cycle assessment of mixed municipal solid waste: Multi-input versus multi-output perspective, Waste Management; 46, pp. 599-611, 2015.

[7] Xu, C., Hong, J., Chen, J., Han, X., Lin, C., \& Li, X., Is biomass energy really clean? An environmental life-cycle perspective on biomass-based electricity generation in China, Journal of Cleaner Production, 133, pp. 767-776, 2016.

[8] Materazzi, M., Lettieri, P., Mazzei, L., Taylor, R. \&. Chapman, C., Reforming of tars and organic sulphur compounds in a plasma-assisted process for waste gasification. Fuel Processing Technology, 137, pp. 259-268, 2015.

[9] Gutiérrez-Gutiérrez, S.C., Coulon, F., Jiang, Y. \& Wagland, S., Rare earth elements and critical metal content of extracted landfilled material and potential recovery opportunities, Waste Management, 42, pp. 128-136, 2015.

[10] Zhou, C., Gong, Z., Hu, J., Cao, A. \& Liang, H., A cost-benefit analysis of landfill mining and material recycling in China. Waste Management, 35, pp. 191-198, 2015.

[11] Directive 2009/28/EC of the European Parliament and of the Council of 23 April 2009 on the promotion of the use of energy from renewable sources and amending and 
subsequently repealing Directives 2001/77/EC and 2003/30/EC. http://eurlex.europa.eu/legal-content/EN/TXT/PDF/?uri=CELEX:32009L0028\&from=EN.

[12] Report from the Commission to the European Parliament, the Council, the European Economic and Social Committee and the Committee of the regions on the implementation of the Circular Economy Action Plan. Brussels (2017) Online, http://ec.europa.eu/environment/circular-economy/implementation_report.pdf. Accessed on: 10 Jan. 2017.

[13] IEA Bioenergy Task 36. Energy recovery from renewable content of waste: incentives and methodology for analysing biogenic content of mixed waste. 2012. http://www.ieabioenergytask36.org/vbulletin/showthread.php?22-Biogenic-contentof-waste-November-2012. Accessed on: 3 Apr. 2016.

[14] Niziolek, A.M., Onel, O., Hasan, M.M.F. \& Floudas, C.A., Municipal solid waste to liquid transportation fuels - Part II: Process synthesis and global optimization strategies. Computers \& Chemical Engineering, 74, pp. 184-203, 2015.

[15] Onel, O., Niziolek, A.M., Hasan, M.M.F., \& Floudas, C.A., Municipal solid waste to liquid transportation fuels - Part I: Mathematical modelling of a municipal solid waste gasifier. Computers \& Chemical Engineering, 71, pp. 636-647, 2014.

[16] Rada, E.C., Energy from municipal solid waste, WIT Transactions on Ecology and the Environment, 190(2), pp. 945-958, 2014.

[17] Aracil, C., Haro, P., Fuentes, D., Gómez-Barea, A., Implementation of waste-toenergy options in landfill-dominated countries: Economic evaluation and GHG impact. Unpublished results.

[18] European Statistics (Eurostat). http://ec.europa.eu/eurostat/data/database. Accessed on: 10 Feb. 2017.

[19] Saunois, M., Jackson, R.B., Bousquet, P., Poulter, B. and Canadell J.G. The growing role of methane in anthropogenic climate change, Environmental Research Letters, 11(12), 2016.

[20] Global Carbon Project (2001) http://www.globalcarbonproject.org/index.htm. Accessed on: 3 Jul. 2016.

[21] Nikolic, A., Mikic, M. \& Naunovic, Z., Broadening the urban sustainable energy diapason through energy recovery from waste: A feasibility study for the capital of Serbia. Renewable and Sustainable Energy Reviews, 69, pp. 1-8, 2017.

[22] Aracil, C., Haro, P., Giuntoli, J. \& Ollero, P., Proving the climate benefit in the production of biofuels from municipal solid waste refuse in Europe. Journal of Cleaner Production, 142, pp. 2887-2900, 2017.

[23] Cherubini, F., Bargigli, S., Ulgiati, S., Life cycle assessment of urban waste management: Energy performances and environmental impacts. The case of Rome, Italy, Waste Management, 28(12), pp. 2552-2564, 2008.

[24] Clausen, A. \& Pretz, T., The relevance of framework conditions for modelling GHG emissions from rMSW treatment systems in EU, Waste and Biomass Valorisation, 7(1), pp. 175-191, 2016.

[25] Fiorentino, G., Ripa, M., Protano, G., Hornsby, C. \& Ulgiati, S., Life cycle assessment of mixed municipal solid waste: Multi-input versus multi-output perspective, Waste Management, 46, pp. 599-611, 2015. 